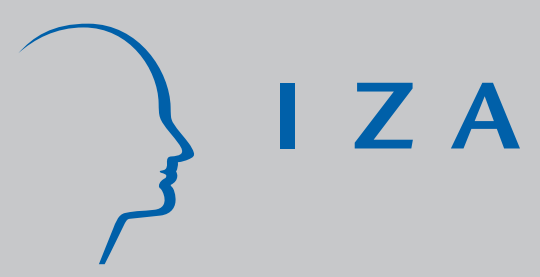

IZA DP No. 582

Equalizing Wage Differences and Bargaining Power: Evidence from a Panel of French Firms

Pierre Cahuc

Christian Gianella

Dominique Goux

André Zylberberg

September 2002 


\title{
Equalizing Wage Differences and Bargaining Power: Evidence from a Panel of French Firms
}

\author{
Pierre Cahuc \\ CNRS-EUREQua, Université Paris 1, CREST, CEPR and IZA Bonn \\ Christian Gianella \\ Direction de la Prévision, Ministère de l'Economie et des Finances, Paris \\ Dominique Goux \\ INSEE, Division Emploi
}

André Zylberberg

CNRS-EUREQua, Université Paris I

Discussion Paper No. 582
September 2002

\author{
IZA \\ P.O. Box 7240 \\ D-53072 Bonn \\ Germany \\ Tel.: +49-228-3894-0 \\ Fax: +49-228-3894-210 \\ Email: iza@iza.org
}

This Discussion Paper is issued within the framework of IZA's research area Evaluation of Labor Market Policies and Projects. Any opinions expressed here are those of the author(s) and not those of the institute. Research disseminated by IZA may include views on policy, but the institute itself takes no institutional policy positions.

The Institute for the Study of Labor (IZA) in Bonn is a local and virtual international research center and a place of communication between science, politics and business. IZA is an independent, nonprofit limited liability company (Gesellschaft mit beschränkter Haftung) supported by the Deutsche Post AG. The center is associated with the University of Bonn and offers a stimulating research environment through its research networks, research support, and visitors and doctoral programs. IZA engages in (i) original and internationally competitive research in all fields of labor economics, (ii) development of policy concepts, and (iii) dissemination of research results and concepts to the interested public. The current research program deals with (1) mobility and flexibility of labor, (2) internationalization of labor markets, (3) welfare state and labor market, (4) labor markets in transition countries, (5) the future of labor, (6) evaluation of labor market policies and projects and (7) general labor economics.

IZA Discussion Papers often represent preliminary work and are circulated to encourage discussion. Citation of such a paper should account for its provisional character. A revised version may be available on the IZA website (www.iza.org) or directly from the author. 
IZA Discussion Paper No. 582

September 2002

\section{ABSTRACT}

\section{Equalizing Wage Differences and Bargaining Power: Evidence from a Panel of French Firms}

In this paper, we develop a dynamic model of firm-level bargaining, along the lines of Manning (1993). In this context, we provide a firm level wage equation that explicitly accounts for firm heterogeneity. This wage equation explains inter-firm wage differentials by differences in labour productivity and job turnover. More precisely, our model predicts that the higher the rate of job destruction within one firm, the higher the compensation of workers. We estimate our wage equation using matched employer-employee panel data in the manufacturing sector, where firms are tracked for five years, between 1988 and 1992. The empirical estimates, using GMM techniques, are fully consistent with our theoretical prediction of equalizing differences: workers who take into account their intertemporal discounted income will support lower wages when they benefit from lower unemployment risks within their firm. In our model, wages are set to maximize a Nash bargain criterion, and according to the estimators used or the industry we consider, we show that workers have an average bargaining power between 0.15 and 0.25 , measured on a scale going from 0 to 1 .

JEL Classification: J33, J51

Keywords: collective bargaining, equalizing wage differences

Corresponding author:

Pierre Cahuc

Université Paris 1- EUREQua

Panthéon-Sorbonne

106-112 Boulevard de l'Hôpital

75013 Paris

France

E-mail:cahuc@univ-paris1.fr 


\section{Introduction}

Union bargaining is often pointed to as a contributor to mass unemployment in France, and primarily among the unskilled workers. Indeed, almost $90 \%$ of French workers are covered by an industry-level collective bargaining agreement. However the priority in collective bargaining is to update job descriptions and classifications used by all firms in the industry. When it deals with wages, it is less concerned by the wages that will effectively be paid by employers than by setting theoretical minimum wages in the industry : in $70 \%$ of the industries these theoretical minima are, in fact, below the actual national minimum wage (Salaire Minimum Interprofessionnel de Croissance or SMIC). In France wage negotiations at the firm level progressively replace negotiations at the industry level withinfirm bargaining. In 1992, only $21 \%$ of firms have signed an agreement on wages with unions or with employees' representatives, according to the Wage Structure Survey (enquête Coûts et Structures). However, a recent study showed that in 1999 France was, with Great-Britain, the only EU country where the firm was the dominant level of wage negotiations ${ }^{1}$. Moreover, with the law about working time reduction to 35 hours a week, an extension of the firm-level bargaining to the level of employment and the working conditions is now observed.

On the whole, there is hence no clear evidence that union bargaining has a major effect on effective wages and it is worth estimating the consequences of collective bargaining on wages in a model that allows us to evaluate the unions' bargaining power. One can distinguish two types of studies that have been devoted to this task. One type of studies analyzes the effect of unions on the structure of wages by comparing compensation of union workers (or of employees who work in firms with at least one union) with compensation of nonunion workers. Araï, Ballot and Skalli (1996) show that the extent of

\footnotetext{
${ }^{1}$ See Gestion Sociale N ${ }^{\circ} 1181$, November 2000.
} 
unionization in the firm raises the workers' wages. Unfortunately, their cross-section estimates do not control for unobserved heterogeneity between workers on the one hand, and between firms on the other and their result could only reflect differences in individual abilities or in the wage policies of the firms rather than an effect of trade unions. Using longitudinal data, Card (1996) shows that unions raise wages more for workers with lower levels of observed skills. A second type of studies utilize bargaining models between unions and employers. Such models yield an equation linking negotiated wages to the bargaining power of unions (or workers). Using matched worker firm panel data, Abowd and Allain (1996) estimate a bargaining power for the employees in France of about 0.4 (measured on a scale going from 0 to 1 ). Their estimate depends on the opportunity cost of the workers, which they construct with microdata. Van Reenen (1996) studied the relationship between innovation and wages on British data and also found a significant elasticity of wages with respect to rents. Using different instrumental variables, Christofides and Oswald (1992) and Blanchflower et alii (1996) obtained a much lower value of this elasticity, but still significantly different from zero.

In this paper, we adopt the second type of approach, that we enrich by focusing on the dynamics of the labor relation. We investigate and estimate a wage equation derived from a dynamic bargaining model, inspired by Manning (1993), in which heterogeneity across firms is introduced. The dynamic approach leads to a simple structural firm-level wagesetting equation where the basic parameter of the workers' bargaining power is present twice. Accordingly this allows us to evaluate the robustness of our results. The second new feature comes from the panel data we used, which is a rich combination of several sources. In particular, our data allow us to control for firm-specific effects and for the heterogeneity of skills within firms. We show that the workers have an average bargaining power of about 0.2, which is close to the estimate provided by Abowd and Lemieux (1993) for Canada. 
Third, our dynamic bargaining model yields a richer wage equation than the usual static one and leads to the following prediction: the higher the rate of job destruction within one firm, the higher the aggregate compensation of workers. Our empirical estimates are fully consistent with this prediction of equalizing differences (Murphy and Topel, 1987): because workers take into account their inter-temporal discounted income, unions will accept lower aggregate wages when the workers (or more precisely the majority of workers) benefit from lower unemployment risks (that is when the firm operates in a more favorable environment, in which the risk of lay offs decreases for the majority of jobs). Consequently, depending on the idiosyncratic shocks faced by each firm, leading to different levels of job destruction, each one will carry out a different wage policy. Our results hence show that differences in job destruction rates may partly explain the interfirm wage differences emphasized by several recent studies which also take into account unobserved characteristics (Abowd, Kramarz and Margolis, 1999, Goux and Maurin, 1999).

Our study is organized as follows. In section II, we present a dynamic model of collective bargaining, along the lines of Manning (1993) for which we consider a non symmetric equilibrium at the firm level. Section III describes our data sources. In section IV, we discuss the econometric estimates of our firm-level wage equation. 


\section{A dynamic model of collective bargaining with heterogeneous firms}

Models of firm-level bargaining used to estimate wage equations are usually standard spot market models of quasi-rent division (Brown and Ashenfelter (1986) or Blanchflower, Oswald and Sanfey (1996)). However, empirical studies highlighted the importance of the process of job creation and job destruction within firms (Abowd, Corbel and Kramarz, 1999) and we can suspect that the history of labor force flows within firms play a role in wage setting. This is illustrated, for instance, by Beaudry and Di Nardo (1991) who estimated a dynamic model of implicit contract and found that wages are much more sensitive to unemployment conditions than most previous studies did.

Considering that the model of collective bargaining is still the most relevant in the case of France, we hence integrate the flows of entry and exit in a dynamic model of quasi-rent division, along the lines of Manning (1993) and Cahuc and Zylberberg (1996). Contrary to Manning, who solves his model in a symmetric equilibrium without heterogeneity, we derive a firm-level wage equation that explicitly accounts for firm heterogeneity. Moreover, we show that the model leads to the same wage equation whether workers and firm bargain on wage only or on wage and employment. Accordingly, contrary to Manning, whose empirical study uses macroeconomic data, we keep the microeconomic dimension of the model and we use panel data to estimate an « exact » firm-level wage equation.

We assume that workers bargain only over wages according to the «right-to-manage» model $^{2}$. Firms decide unilaterally the level of employment, after wages are set by collective bargaining. Time is discrete and, at each date, the economy works according to the following sequence of decisions (see Appendix 1) :

a. At the end of each production period $(t)$, technological shocks occur and an exogenous proportion $\left(q_{t}^{i}\right)$ of employees of firm $i$ are fired. 
b. At the beginning of next period $(t+1)$, each firm and its employees bargain over the current wage and the agreement obtained is supposed to hold for a single period.

c. Then, each firm $i$ determines its level of employment $\left(L_{t+1}^{i}\right)$. This adjustment is made either by hiring workers if $L_{t+1}^{i} \geq\left(1-q_{t}^{i}\right) L_{t}^{i}$, or by firing workers if $L_{t+1}^{i}<\left(1-q_{t}^{i}\right) L_{t}^{i}$

d. Production occurs, output is sold, wages are paid and new shocks occur at the end of period $(t+1)$. We will now turn to the precise description of firms and workers' behavior.

II.1. Firms

The profit maximisation

There is a continuum of firms in the economy of density 1 on $[0,1]$. For now, we do not make any assumption about the market of goods, which can be either perfectly or imperfectly competitive. We denote by $R\left(A_{t}^{i} L_{t}^{i}\right)$ the revenue function of firm $(i)$, where $L_{t}^{i}$ is the level of employment and $\left(A_{t}^{i}\right)$ a parameter of productivity ( $R$ is increasing and concave $)^{3}$. At each period, firms face two types of technological shocks : shocks on the productivity parameter $\left(A_{t}^{i}\right)$ and idiosyncratic shocks on a certain proportion $\left(q_{t}^{i}\right)$ of jobworker pairs. When a job-worker pair experiences such an adverse technological shock it becomes unproductive at the end of the period and it separates.

According to the sequence of decisions previously defined, firms determine the level of employment after the wage determination process. Let $\rho_{t}$ denote the tax wedge (including

\footnotetext{
${ }^{2}$ As seen in Appendix 2, devoted to the case of bargaining on wage and employment, this assumption is not essential to derive the wage equation we will use for our estimations.

${ }^{3}$ We could easily re-write our model with capital. It does not change the forthcoming development but complicates the presentation (see Cahuc and Zylberberg, 1999).
} 
both employer-paid and employee-paid payroll taxes) and let $w_{t}^{i}$ be the net real wage in firm $i$. The firm $i$ maximizes its current profit $\pi_{t}^{i}$.

$$
\operatorname{Max}_{L_{t}^{i}} \pi_{t}^{i}=R\left(A_{t}^{i} L_{t}^{i}\right)-\rho_{t} w_{t}^{i} L_{t}^{i}
$$

The first order condition of (1) defines a labor demand function $L_{t}^{i}\left(\rho_{t} w_{t}^{i}\right)$ such that:

$$
\forall t \geq 0 \quad \mathrm{~A}_{\mathrm{t}}^{\mathrm{i}} \frac{\partial R}{\partial L}\left(A_{t}^{i} L_{t}^{i}\right)=\rho_{t} w_{t}^{i}
$$

\section{The technological shocks}

Both types of technological shocks $\left(A_{t}^{i}\right)$ and $\left(q_{t}^{i}\right)$ are assumed exogenous. We decompose the productivity parameter $\left(A_{t}^{i}\right)$ in two components: a temporal component of technical progress, common to all firms in the economy, and an individual component which represents a specific shock. So the productivity parameter can be written $A_{t}^{i}=\phi_{t}+\eta_{t}^{i}$. We also assume that $\left(\eta_{t}^{i}\right)$ and $\left(q_{t}^{i}\right)$ are random variables which distribution is identical across firms and which are known only at the beginning of the period before wages are negotiated. The two types of shocks can of course be correlated within one period, but we assume that they are independent across time. So both $\left(\eta_{t}^{i}\right)$ and $\left(q_{t}^{i}\right)$ are $\operatorname{iid}^{4}$. This is not necessarily the case for the productivity $\left(A_{t}^{i}\right)$, since we do not make any hypothesis on the evolution of the technical progress $\left(\phi_{t}\right)$.

\section{The job destruction rate}

We solve the model in the case $L_{t+1}^{i} \geq\left(1-q_{t}^{i}\right) L_{t}^{i}$. In our model it implies that, given the shocks on job-workers pairs $\left(q_{t}^{i}\right)$ and workers' anticipations on the productivity parameter $\left(A_{t}^{i}\right)$, insiders who stayed in the firm negotiate the wages so that they keep their job for at 
least one period. This condition requires that the productivity shocks on $\left(A_{t}^{i}\right)$ are not strongly adverse or, equivalently, that the exogenous separation rate $q_{t}^{i}$ is sufficiently high. This is a reasonable assumption in the case of a growing economy, for which the

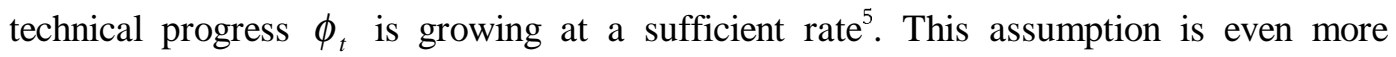
relevant in the case of a growth through creative destruction (Aghion, Howitt, 1992). Furthermore our data cover the period 1988-1992, which is a period of expansion ${ }^{6}$, where dismissals are more likely to be caused by exogenous shocks rather than too high wages.

This assumption could however still be challenged in the case of an economy in recession, but recent empirical findings support its general validity. The study of Abowd, Corbel and Kramarz (1999) on French data shows first that there is considerable simultaneous hiring and separation, and second that when a firm is shrinking, the adjustment of employment is made by reducing entry and not by increasing the separation rate. In fact, the French labor market was characterized by a strong increase in short term contracts in the late 80 's. As only a few proportion of these contracts are extended in long term contracts, this development contributed to raise the proportion of workers who leave the firm for exogenous reasons, or more precisely for other reasons than the economic situation of firms.

Finally, our data support this theoretical assumption. First, almost all the firms have a strictly positive hiring rate, for all the years of observation. Second, we find no correlation between the rate of dismissals and the variation of employment in our panel (see section III).

\section{II.2. Workers}

\footnotetext{
${ }^{4}$ This assumption has an empirical support an empirical support : Goux and Maurin (1999) show that inter-industry wage differences are not structural.

${ }^{5}$ In the neighbourhood of equilibrium, when employment is growing at a constant rate, we can even have the condition $L_{t+1}^{i}>L_{t}^{i}$.

${ }^{6}$ The average growth rate in France was 2.8\% over the period 1988-1992.
} 
There is a continuum of individuals in the economy of density $\mathrm{N}$ on $[0,1]$. We assume perfect homogeneity and mobility of the labor force : all individuals are identical and can apply for any job in any firm without search costs. Furthermore, agents are risk-neutral, have an infinite life-time horizon, and supply one unit of labor at every date $t$. Each worker employed in firm $i$ is paid the net real wage $w_{t}^{i}$ and, as explained before, loses his job at the end of period $t$ with a probability $\left(q_{t}^{i}\right)$. In this case, he can immediately seek a new job and is employed at period $\mathrm{t}+1$ with probability $a_{t+1}$.

Under these assumptions we can define the value functions of the employees and the unemployed workers. The expected revenue of an employee in the firm $i$ at the beginning of the period $\mathrm{t}$ can be written as follows :

$V_{t}^{i}=w_{t}^{i}+\beta\left[q_{t}^{i}\left(a_{t+1} \bar{V}_{t+1}^{e}+\left(1-a_{t+1}\right) \bar{V}_{t+1}^{u}\right)+\left(1-q_{t}^{i}\right) V_{t+1}^{i}\right]$

where $\beta$ is the discount factor, $\bar{V}_{t+1}^{e}$ the expected value of being employed elsewhere at $t+1, V_{t+1}^{u}$ the expected value of being unemployed at $t+1$ and $\nabla_{t+1}^{i}$ the expected value of being employed next period in the firm $i$.

According to our assumption on the process of the shocks $\left(A_{t}^{i}\right)$ and $\left(q_{t}^{i}\right)$, expectations about future wages and future job destructions are uniform across firms. Hence the expected value of being employed in the same firm next period $\left(\bar{V}_{t+1}^{i}\right)$ is equal to the expected value of being employed elsewhere $\left(\bar{V}_{t+1}^{e}\right){ }^{7}$

\footnotetext{
${ }^{7}$ We thus suppose that being fired is not a signal of the poor quality of the worker. Notice however that it is possible to solve and estimate the model without making this assumption. We have chosen a simple representation of expectations. We could have kept heterogeneity in the anticipated value functions of being employed, but in fact it is not worth doing so, since the developments are more complicated and the results almost unchanged. This assumption can be
} 
Let $z_{t}$ denote the level of real unemployment benefits ${ }^{8}$ and $\left(1-\eta_{t+1}\right)$ denote the probability that a worker who is unemployed this period remains unemployed next period ${ }^{9}$ The value of being unemployed at date $t, V_{t}^{u}$, is then given by

$V_{t}^{u}=z_{t}+\beta\left(\eta_{t+1} V_{t+1}^{e}+\left(1-\eta_{t+1}\right) \bar{V}_{t+1}^{u}\right)$

\section{II.3. Insiders and firms objective function}

Wages are set at the beginning of each period after a bargaining process at the firm level between employers and unions. We have seen in the previous section that insiders who negotiate keep their job during the period. It is therefore useless for them to have an employment objective during the negotiations. When negotiations break down, workers quit the firm $i$ and have some employment opportunities elsewhere with the same probability $a_{t}$ as a worker who has just been fired. The expected utility of workers after negotiations have been broken off is ${ }^{10}$

$V_{t}^{g}=a_{t} V_{t}^{e}+\left(1-a_{t}\right) V_{t}^{u}$

The fall-back payoff of workers is then $V_{t}^{g}$ and their objective function in the Nash criterion is simply the difference $\left(V_{t}^{i}-V_{t}^{g}\right)$. Since there is no on-the-job search in the

justified by several empirical studies about inter industry wage differentials : Abowd, Kramarz and Margolis (1999) or Goux and Maurin (1999) have shown that these differentials reflect primarily the differences in measured and unmeasured labor quality. The average variation in wages for workers who switch industries does not exceed $3 \%$.

${ }^{8}$ In fact the term $z_{t}$ represents not only unemployment benefits, but also all replacement income and the non monetary utility or disutility of being out of work. It is therefore closer to an opportunity cost.

${ }^{9}$ The probability of being reemployed can be different for short term or long term unemployed. However unemployment duration has no effect on workers' productivity.

${ }^{10}$ The fall-back point is never reached and negotiations are always successful. 
model, it is not in the workers' interest to quit their employers; if they do so they will only obtain $V_{t}^{g}$ which is always lower than $V_{t}^{i}$.

Under the assumption of constant and exogenous real interest rate $r$, the expected profit of each firm $i$, denoted $\Pi_{t}^{i}$, can be written

$$
\Pi_{t}^{i}=\left(\pi_{t}^{i}\right)^{*}+\frac{1}{1+r} \Pi_{t+1}^{i}
$$

where $\pi_{t}^{i^{*}}$ is the maximum of the current profit defined in section II.1 by equation (1).

When negotiations break down, the situations of workers and firms are asymmetric: workers who leave the firm immediately seek another job, while for firms it is impossible to fire the workers on strike and to replace them immediately at date $t^{11}$. In the case of strike, firms produce nothing and current profit $\pi_{t}^{i}$ is therefore zero. However, forthcoming profits are not modified because firms can hire workers for the next period without adjustment costs. Under these assumptions, the fall-back position of each firm is $\Pi_{t}^{o, i}=\frac{1}{1+r} \Pi_{t+1}^{i}$ and its objective function is the current profit $\left(\pi_{t}^{i}\right)^{*}=\Pi_{t}^{i}-\Pi_{t}^{0, i}$.

\section{II.4. Within firm wage determination}

We assume that the outcome of the negotiations is given by the maximization of a Nash bargaining program. Workers are rational and know that firms are on their labor demand curve. The issue of negotiations is given by the following program :

$$
\underset{w_{t}^{i}}{\operatorname{Max}}\left[R\left(\mathrm{~A}_{\mathrm{t}}^{\mathrm{i}} L_{t}^{i}\left(\rho_{\mathrm{t}} \mathrm{w}_{\mathrm{t}}^{\mathrm{i}}\right)\right)-\rho_{\mathrm{t}} w_{t}^{i} L_{t}^{i}\left(\rho_{t} w_{t}^{i}\right)\right]^{1-\gamma}\left[V_{t}^{i}-V_{t}^{g}\right]^{\gamma}
$$

\footnotetext{
${ }^{11}$ This is justified by institutional delays or legal restrictions on firing.
} 
where $\gamma$ is the bargaining power of unions $(0<\gamma<1)^{12}$. Using equation (2) and the « envelope theorem » the first order condition implies ${ }^{13}$ :

$V_{t}^{i}-V_{t}^{g}=\frac{\gamma}{1-\gamma} \frac{1}{\rho_{t}}\left[\frac{R\left(A_{t}^{i} L_{t}^{i}\right)}{L_{t}^{i}}-\rho_{t} w_{t}^{i}\right]$

It should be noted that equation (8) could also be derived in the case of an efficient contract model, where unions also bargain over employment (see Appendix 2).

Denoting $w_{t}^{i}+\chi_{t}^{i}=V_{t}^{i}-V_{t}^{g}$, equation (8) gives after some rearrangement the expression of the wage set in firm $i$ as an implicit function of the exogenous parameters and of the expected values functions of date $t+1$.

$$
w_{t}^{i}=\frac{\gamma}{\rho_{t}} \frac{R\left(A_{t}^{i} L_{t}^{i}\right)}{L_{t}^{i}}+(\gamma-1) \chi_{t}^{i}
$$

The term $\chi_{t}^{i}$ can be rewritten using relations (3), (4) and (5)

$$
\chi_{t}^{i}=-z_{t}+\beta\left(1-q_{t}^{i}\left(1-a_{t+1}\right)-\eta_{t+1}\right)\left(\bar{V}_{t+1}^{e}-V_{t+1}^{\partial^{u}}\right)-a_{t}\left(V_{t}^{e}-V_{t}^{u}\right)
$$

In order to eliminate the differences of values functions $V_{t}^{e}-V_{t}^{u}$ and $\bar{V}_{t+1}^{e}-\bar{V}_{t+1}^{u}$, we use equation (5), which gives $V_{t}^{e}-V_{t}^{g}=\left(1-a_{t}\right)\left(V_{t}^{e}-V_{t}^{u}\right)$, and we take the expectation value in equation (8). We obtain :

$$
V_{t}^{e}-V_{t}^{g}=\frac{\gamma}{1-\gamma} \int_{0}^{1}\left[\frac{R\left(A_{t}^{i} L_{t}^{i}\right)}{\rho_{t} L_{t}^{i}}-w_{t}^{i}\right] d i=\frac{\gamma}{1-\gamma}\left[\frac{A L P_{t}}{\rho_{t}}-\bar{w}_{t}\right]
$$

\footnotetext{
${ }^{12}$ Empirically, we will consider a short period of time, so that $\gamma$ can be considered constant over time. We will challenge the hypothesis that $\gamma$ is constant across firms by running estimations for different industries.

${ }^{13}$ The second order condition holds if $\gamma$ is not too high, i.e. if $\gamma<\varepsilon_{L, w} .(\rho w L /(R(A L)-\rho w L))$ where $\varepsilon_{L, w}$ is the wage elasticity of labour demand. With our data we find the condition $\gamma<2 \varepsilon_{L, w}$ which is usually valid, since several empirical studies show that this elasticity is around 0.5 (see Dormont 1993).
} 
where $A L P_{t}$ is the average labor productivity in the economy and $\bar{w}_{t}$ the average net wage in the economy at date $t$.

Finally $\chi_{t}^{i}$ is determined by (10) and (11). The wage equation in each firm can be expressed in the following way :

$$
w_{t}^{i}=\gamma \frac{R\left(A_{t}^{i} L_{t}^{i}\right)}{\rho_{t} L_{t}^{i}}+(1-\gamma) z_{t}+\gamma \frac{a_{t}}{1-a_{t}}\left(\frac{A L P_{t}}{\rho_{t}}-\bar{w}_{t}\right)-\gamma \beta\left(\frac{1-\eta_{t+1}}{1-a_{t+1}}-q_{t}^{i}\right) E\left\{\frac{A L P_{t+1}}{\rho_{t+1}}-\bar{w}_{t+1} \mid \Omega_{t}\right\}
$$

where $E$ denotes the expectation operator conditionally on $\Omega_{t}$, the set of information available at date $t$.

The wage $w_{t}^{i}$ is an implicit solution of equation (12), as the level of employment (and then the level of productivity) depends on wages. However equation (12) shows that the negotiated wages depend on the one hand on firm specific variables, such as productivity and the rate of job destruction, and, on the other hand, on external parameters (at the firm level) such as unemployment benefits, aggregate productivity, aggregate labor cost and the unemployment rate ${ }^{14}$.

Giving a specific form to $R\left(A_{t}^{i} L_{t}^{i}\right)$ allows to explicit $w_{t}^{i}$. In the simple case of a CobbDouglas production function, $R\left(A_{t}^{i} L_{t}^{i}\right)=\left(A_{i}^{t} L_{i}^{t}\right)^{\alpha}$, we can derive the explicit wage equation.

$$
w_{t}^{i}=\alpha \frac{1-\gamma}{\alpha-\gamma} z_{t}+\gamma \frac{1-\alpha}{\alpha-\gamma}\left[\frac{a_{t}}{1-a_{t}} \bar{w}_{t}-\beta E\left[\left(\frac{1-\eta_{t+1}}{1-a_{t+1}}-q_{t}^{i}\right) \bar{w}_{t+1} \mid \Omega_{t}\right]\right]
$$

Since $\gamma<\alpha<1$, wages are increasing with the bargaining power of unions $(\gamma)$. They are also increasing with the unemployment benefits, the average wage in the economy $\bar{w}_{t}$ and

\footnotetext{
${ }^{14}$ The aggregate level of unemployment in the economy has an influence on the negotiated wage through the probabilities of finding a job. It is easier to see this point by writing the equilibrium
} 
with the probability of finding another job $\left(a_{t}\right)$ : in fact all these parameters give the unemployed people a higher fall-back position in the negotiation. On the contrary, wages are decreasing with the average anticipated wage at date $(t+1)$, because higher wages' opportunities in the future increase the value of being employed today, and also decreasing with the parameter $\frac{1-\eta_{t+1}}{1-a_{t+1}}$ which measures the discrimination against long term unemployed people. Taxes are not neutral in our model, since an increase in the tax wedge reduces simultaneously profits, and hence decreases net negotiated wages, and the level of employment, which leads to an increase in productivity. In the case of the Cobb-Douglas production function, the wedge is neutral on the net wage, because both effects exactly compensate.

The most remarkable result concerns the positive impact of the rate of job destruction $\left(q_{t}^{i}\right)$ on negotiated wages. Workers intend to maximize their discounted revenues and to maintain the mark-up of the value of employment $V_{t}^{i}$ over $V_{t}{ }^{g}$ constant. Hence the higher the risk of losing one's job, the higher the wage to compensate for this risk. Putting it in another way, workers, who take into account their intertemporal discounted revenue, will accept lower wages when they benefit from lower unemployment risks ${ }^{15}$ The wage bargaining mechanism leads to « equalize differences » between firms. ${ }^{16}$

\section{The Data}

III.1. The merging of three panels at the firm level

of employment flows (see Cahuc and Zylberberg, 1996). Wages are of course decreasing with the unemployment rate.

${ }^{15}$ This apply to the common risks faced by the majority of workers and not the specific individual risks (which are not present in our theoretical model).

${ }^{16}$ We can observe that when workers bargain over employment -see appendix 2- and agree to a wage decrease in return for a lower rate of dismissals, they behave exactly as the model predicts. 
The data are derived from the merging of three annual surveys by the Institut National de la Statistique et des Etudes Economiques (INSEE) and the Direction de l'Animation de la Recherche des Etudes et des Statistiques (DARES), two main governmental statistics agencies. We matched the Occupational Structure Survey (Enquête sur la Structure des Emplois, ESE), the Monthly Worker Movement Declaration (Déclarations de Mouvements de Main-d'Oeuvre, DMMO) and the Survey of Corporate Tax Returns (Bénéfices Industriels et Commerciaux, BIC). The sample contains about 1,000 firms, from the private manufacturing sector, with at least 50 employees. The sample is balanced over the period 1988-1992, so that the number of available observations is around 5,000 ${ }^{17}$. For each firm and for each year, the sample covers the data items that are standard in surveys of this kind: value added, turnover, output, wage bill (total labor costs) and the occupational structure using a 4-digit standardized classification of occupations. From this classification, we use only six positions : (1) managers and professionals; (2) technicians and supervisors; (3) skilled clerical workers; (4) unskilled clerical workers; (5) skilled manual workers; and (6) unskilled manual workers.

One of the interesting features of our panel is that it provides the number of employees fired and makes it possible to distinguish (1) quits; (2) endings of short-term contracts (Contrats à Durée Déterminée, CDD); (3) contracts terminated for economic reason or for cause; and (4) retirements, early retirements and other reasons. For each firm, the job destruction rate is calculated as follows : we sum the rate of lay-offs (redundancy and dismissals) and the rate of destruction of short-term contracts. Statistically dismissals accounts only for a small part of the job termination. There are more likely to lead to new hirings, but this distinction is not relevant in our theoretical model : what is important for

In this case the probability of being fired becomes endogenous and is simultaneously set with wages.

${ }^{17}$ We are grateful to Marianne Pauchet who kindly gave us the access to the original matched data source she created on the basis of a panel put together by S. Lagarde, E. Maurin and C. Torelli (Lagarde, Maurin and Torelli, 1995). We supplemented this panel with other industrial and geographical variables. 
an insider is his own risk of loosing his job (and this risk of dismissal could be higher in some firms of for specific jobs). Voluntary quits are not considered as job destruction and it is therefore implicitly assumed that such exits lead to new hirings. In the model, all individuals are supposed identical. Gross differences in average wages between firms reflect mostly differences in the occupational structure : a company which employs 5 managers and 5 unskilled manual workers will surely have a higher wage bill than another one which employs 1 manager and 9 unskilled manual workers, even if both unskilled manual workers and managers receive the same compensation. To take into account the «quality » of the labor force specific to each firm, we calculate, at each date and for each firm, the equivalent wages for unskilled manual workers ${ }^{18}$.

Average productivity and labor costs are estimated from the BIC, for the same sector as our panel, i.e. manufacturing industries. Each year, this survey consists of about 26,000 companies. It makes it possible to measure the average productivity and the average labor cost for the 1987-1993 period. Productivity is supposed to be equal to the value added per employee. ${ }^{19}$ Table 1 shows summary statistics for the firm-level variables used in our statistical analysis and table 2 the decomposition of variance for these variables. It is not necessary to compute additional macroeconomic data such as income of the unemployed people and the rates of job creations $\left(a_{t}\right)$ or $\left(\eta_{t}\right)$, since they will be disappear with the introduction of time dummies.

III.2. The rate of job destruction

\footnotetext{
${ }^{18}$ The French Labour Force Surveys, from 1987 to 1993, allow the estimation of relative wages of the six occupational positions identified in each firm. Between occupations average wage differences are rather constant over time : in average, a professional or manager earns three times more than an unskilled manual worker, a technician or supervisor 1.8 time more, a skilled clerical worker 1.2 time more, a skilled manual worker 1.3 time more and an unskilled clerical worker 1.2 time less.

${ }^{19}$ In our model, the output per employee would be less appropriate, because the purchasing costs of intermediate consumer goods are not taken into account.
} 
Summary statistics on the average rate of exit and entry of workers are reported in table 3. These statistics confirm that when a firm reduces the number of employees, it reduces the number of entries. It can also be observed that the entry and the exit rates are higher in firms with increasing employment than in firms with decreasing employment. The average value of the rate of job destruction we consider is $10.8 \%$ over the whole period (see table 1). It represents about half of total job outflows. We do not take into account quits in the definition of the rate of job destruction, because quits rather are an endogenous process, which we have not considered in our model ${ }^{20}$.

A simple calculation of the Pearson correlation coefficient between the rate of job destruction within a year and the variation of employment is equal to 0.012 and is not statistically different from zero. It is also worth noting that the entry rate is superior to the exit rate in $80 \%$ of the cases, a fact which supports the interpretation of shocks on jobworker pairs. Another feature confirms our interpretation of terminations: the rate of job destruction is not correlated with lagged wages. We can not therefore accept the conclusion that higher $\left(q_{t}^{i}\right)$ are synonymous with decreasing employment because of higher wages.

As we merge three different databases, it is clear that our final panel is biased towards bigger firms. The robustness of the model has been challenged by conducting estimates by size of firms, with the same kind of results, but are not reported here.

\section{Empirical results}

We estimate in this section the bargaining power of workers and the discount factor of workers from the structural equation (12). In order to take into account the heterogeneity of industries, which economic situation could be very different at each period of time, we

${ }^{20}$ However, we could have assumed that workers who quit their firm find another job immediately, and these flows would not have had any influence in our model if they occur before the wage bargaining process. 
systematically include dummies for the different industries ${ }^{22}$ in our regressions, as well as time dummies $^{23}$. This inclusion allows us to avoid the difficulty of measuring the level of replacement income $\left(z_{t}\right)$. It is possible to calculate an indicator of replacement incomes for unemployed people from the Labor Force Survey, but the data in this survey are not very reliable, and would neglect the influence of various allocations (mother's help, home help etc.). For all those reasons it seems reasonable to replace the term $(1-\gamma) z_{t}$ in equation (12) by temporal cross industrial dummies. By the way we do not need to calculate either the rates of exit from unemployment $\eta_{t}$ and $a_{t}$. Finally equation (12) becomes :

$$
w_{t}^{i}=c+\gamma \cdot \frac{R_{t}^{i}}{\rho_{t} L_{t}^{i}}+\beta \gamma \cdot q_{t}^{i}\left(\frac{A L P_{t+1}}{\rho_{t+1}}-\bar{w}_{t+1}\right)+\delta_{t} * \delta_{s}+u_{i t}
$$

where $\mathrm{c}$ is a constant, $\delta_{t}$ a time dummy, $\delta_{s}$ a dummy for the industry $\mathrm{s}$ and $u_{i t}$ the error term, assumed uncorrelated through time.

The coefficients $(\gamma)$ and $(\beta)$ are then identified only by time-varying and individual -varying independent variables. The bargaining power $(\gamma)$ appears twice in equations (14). A first strategy to estimate this parameter would consist in fixing arbitrarily a value of the discount factor $(\beta)$ compatible with the real interest rate on financial markets. This rate is approximately constant around 5\% over the period 1988-1992, giving a value for $\beta$ of 0.95. But it is not obvious that workers have an easy access to financial markets and take the same interest rate into account. They could be either more or less patient than capital owners. We hence estimate (14) without giving an a priori value to the discount factor.

In the theoretical model, the labor productivity is endogenous and depends on the wage set within the firm. In a first step we ignore this source of endogeneity in our estimations and

\section{INCORPORER}

${ }^{22}$ At the level of the French nomenclature NAP 40, which is presented in table 6.

${ }^{23} \mathrm{We}$ have in fact transformed our variables so that their average value by industries cross time is equal to zero. 
run Least Square Estimates, as a benchmark. In a second step we run GMM estimates, which take into account the sources of potential biases.

a) OLS, within and FGLS estimates

The OLS estimate of equation (14) confirms the rent-sharing mechanism and shows that the bargaining power of workers is around 0.22 (table 4, column 1). The most striking result is however the strong validation of the equalizing wage differentials prediction since the sign of the estimator $\hat{\gamma \beta}$ is positive and the coefficient is significant (row 2). Wages are an increasing function of the rate of job destruction. The estimated coefficient $\hat{\gamma \beta}$ is relatively low, about 0.14 , which gives a small value of the discount factor $(\hat{\beta}$ is slightly greater than 0,6$)$.

It is however possible that some key firm-level determinants of wages may be correlated with the independent variables. If that is so, OLS estimates are biased. Theoretically, one can imagine that the shocks are persistent $\left(A_{t}^{i}=\phi_{t}+\alpha_{i}+v_{i t}\right)$ which also induces that there is a firm specific component in the determination of wages. Therefore we performed two specification tests : the Fischer test for the existence of an individual effect and the Hausman test which compares «between » and «within » estimates, in order to check whether the individual effect is correlated with the explanatory variables or not. Results are reported in table 4 . These tests show there exist individual effects and that these individual effects are fixed effects.

The within firm and first difference estimators enable us to get rid of this bias. Once we take firm specific policy into account, the bargaining power of workers $(\gamma)$ is smaller and fluctuates around 0.16 and 0.18 for within, first difference and long difference estimators (table 5). It is worth noting that the estimates of $(\gamma)$ are almost similar. However this is not 
the case for $\hat{\beta}(=\hat{\beta} / \hat{\gamma})$, which is greater than one in the first difference estimates : it would mean that agents give more weight to the future than to the present. The effect of measurement errors on first differences estimates is however potentially important and long difference estimator is much more satisfactory, even if not precise $(\hat{\beta}$ is around 1$)$.

Another source of potential bias in the previous estimates lies in the possibility of heterogeneity in the bargaining power. First it is possible that the bargaining power of workers depends on the size of the productivity per worker, the size of the firm or the rate of job loss. However Abowd and Allain (1996) have shown that the first hypothesis is not consistent with their empirical results. The second must be rejected too, because if we allow $\gamma$ to be linearly dependent on $\left(q_{t}^{i}\right)$ or on $\left(L_{t}^{i}\right)$ the corresponding coefficient is not significant $^{24}$.

It could also be argued that the positive relationship we find between wages and the rate of job destruction is due to the fact that firm first layoff less efficient workers. Several simple arguments suggest to reject this interpretation :

- First, we control for the observed skills in the way we compute wages.

- Second the rates of job destruction for the different skills usually exhibit the same evolution within firms. It means that when the risk of unemployment increases it increases for every type of workers.

- Third, when the wage equation (14) is estimated only on firms with increasing employment the relationship still holds.

- Fourth and above all, the relationship (14) links current wages to the future risk of unemployment. So it is not possible for wages to increase before the less productive workers are fired.

\footnotetext{
${ }^{24}$ If we replace $\gamma$ by $\gamma_{t}^{i}=\gamma_{0}+\gamma_{1} q_{t}^{i}$ (respectively $\gamma_{t}^{i}=\gamma_{0}+\gamma_{2} L_{t}^{i}$ ) the coefficient $\gamma_{1}$ (respectively $\gamma_{2}$ ) is not significant.
} 
Second, the bargaining power could be heterogeneous between industries, since collective agreements are often signed at the industry level. Table 6 reports within and QGLS ${ }^{25}$ estimates at two levels of aggregation. As we only have a few number of observations in our sample for some industries, we first consider a rough decomposition in three different sectors : the intermediate manufactured products industries, the equipment goods industries and the consumer goods industries. We also compute the within and QGLS estimates for a level of aggregation which corresponds to the industry collective bargaining agreement. The tests show that there are firm specific effects within each industry, but they are not always correlated to the explanatory variables (in some case the QGLS estimates is convergent and optimal). It is quite remarkable to see that the bargaining power coefficient $\gamma$ is stable across industries, it varies between 0.15 and 0.25 , and is always significant. The coefficient seems to be lower in mining, steel and ferrous industries, in chemicals and in paper and board industries (about 0.1), but the number of firms for these industries in our sample is low. The parameter $\hat{\beta}$ fluctuates usually between 0.5 and 1 , with absurd values for paper and board industry and rubber industry ( $\hat{\beta}$ is greater than 1 , but we do not have many firms for these sectors). Anyway these estimations by industry confirm the result of equalizing wage differences and, except for small sectors, the firms we consider seem to be behave in their wage setting in a rather homogenous way across sectors. Estimations by size of firms were also conducted, with the same kind of results, but are not reported here.

\section{b) Generalized Method of Moments Estimates}

${ }^{25}$ QGLS stands for Quasi-Generalized Least Squares. 
As we have already pointed out, especially for labor productivity, independent variables may be endogenous. In the theoretical model, wages, employment, quasi-rent per worker are jointly determined, so that the OLS estimates, as well as the within estimates, of $\gamma$ and $\gamma \beta$ are potentially inconsistent. Measurement errors are another potential source of bias. For example the corporate entity for which financial information is available does not always correspond to the firm involved in collective bargaining. Hence we have to adopt the Generalized Method of Moments (henceforth GMM) to estimate the model.

We write the model in first differences in order to eliminate the individual fixed-effect. Equation (14) becomes, for each firm $(i)$ at every date $(t)$ :

$$
\Delta w_{t}^{i}=\gamma \cdot \Delta \frac{R_{t}^{i}}{\rho_{t} L_{t}^{i}}+\beta \gamma \Delta q_{t}^{i}\left(\frac{A L P_{t+1}}{\rho_{t+1}}-\bar{w}_{t+1}\right)+d_{t}+u_{i t}-u_{i t-1} \text { with } d_{t}=\delta_{t}-\delta_{t-1}
$$

GMM estimation allows us to take a large number of moment conditions to estimate the model. Following Arellano and Bond (1991), we use the conveniently lagged left-hand variable as an instrument as well as lags of independent variables. We assume that our explanatory variables are weakly exogenous, so that the disturbance is uncorrelated with strictly past values of the regressors. We will use these instruments in levels with at least two lags, and not in first differences, in order to keep an additional year of data.

Moreover, we will use other exogenous instruments to get other moment conditions. Following Abowd and Allain (1996), the instrumental variables used are the sector-based prices of imports and prices of exports (600-heading classification of industries, NAP600). We use also the Herfindhal index, which measures the concentration of the various markets covered by the firm. Several studies have in fact detected a positive link between the rentsharing and the product market power of firms (see for example Rose, 1987). In our panel, this index is correlated with the added value of the firm (correlation of 0.19 ). We could however suspect that the bargaining power of unions is greater in firms which operate in less competitive industries. We have tested this hypothesis by specifying in our wage 
equation a bargaining power which depends linearly on the Herfindhal index ${ }^{26}$. In our sample we find no effect of this index on the bargaining power, when we estimate such an equation with instrumental variables. To take the opportunity cost of working into account, we add the regional unemployment rate and the regional average wage in the set of instruments. The rate of job destruction could be not strictly exogenous, especially if unions also bargain over employment (see the model in appendix 1). In this model, the mechanism of equalizing wages still holds, but becomes partly endogenous : unions accept lower wages against an increase in job creation. For the job destruction rate, we use its lagged values as instrumental variables, and also the lag of the turnover rate. The latter seems to be a better instrument. To check the validity of our instruments, we use the Sargan test of overidentifying restrictions from the two-step GMM estimator.

We give the results for the one-step estimator and the two-step estimator (see table 7). For the three sets of instruments the test of overidentification is quite satisfactory as well as the test of compatibility between exogenous instruments and lagged explanative variables. With the complete set of instruments we obtain a value of the bargaining power of about 0.19 (model c). The discount factor is equal to 0.77. After correcting the first differences estimator from the endogeneity and measurement errors bias, it is worth noting that the coefficient $\beta$ becomes less than one. We retain these values $(\gamma=0.19$ and $\beta=0.77)$ as our best estimates.

The theoretical model assumed the rate of job destruction was exogenous. The econometrics tests do not reject this hypothesis : if we compare the values obtained with GMM techniques and within estimator and if we run an Hausman-Wu test (for the global model), we can not reject the hypothesis of equality between these estimates.

We finally conduct a GMM estimation by industry (table 8 ) and compare the results to the estimates obtained by within and QGLS estimates (table 6). For some industries there are

\footnotetext{
${ }^{26} \gamma$ is replaced by $\gamma_{t}^{i}=\gamma_{0}+H I_{t}^{i} \cdot \gamma_{1}$ where $\mathrm{HI}$ is the Herfinhal index.
} 
not enough individuals to run a GMM procedure with the complete set of instruments (chemicals industry and paper and board industry). The estimates are very close, and the bargaining power seems to be a little higher for the finest level of aggregation with GMM estimates. When we aggregate in three sectors $\gamma$ is lower than the within estimate for the two step estimator. Finally, the discount rate becomes lower than one for wood and furnitures and rubber products industries. And for mining, steel work industries and printing and publishing, the equalizing differences coefficient $\gamma \beta$ has increased, especially for printing and publishing. The GMM estimations by industries hence fully confirm the theoretical model. We find little heterogeneity among sectors, especially for the bargaining power : it usually fluctuates around 0.2 while the discount rate ranges approximately from 0.5 and to 1 (or sometimes more than one). The discount factor of workers is usually lower than the discount rate on financial markets and it justifies the assumption of not imposing an a priori value to this parameter. These sector-based estimations show that composition effects should not influence strongly our estimation for the entire sample, and confirm that the endogeneity bias is weak.

Notice finally that the bargaining power we found is lower than the value obtained for France by Abowd and Allain (1996) and much closer to the result found by Abowd and Lemieux (1993) for Canada (0.2 in the later case). 


\section{Conclusion}

In this paper, we have shown that the rent sharing mechanism can not be neglected for France. The estimation of a structural model of collective bargaining gives an estimated bargaining power of about 0.2 in the manufacturing industries. This result is consistent with the findings of Abowd and Lemieux (1993) and Van Reenen (1996) on Canadian and British datasets. We also show how important it is to take into account firm specific effects and the heterogeneity of skills within firms to avoid an overestimation of this rent sharing mechanism. We however find that there is no strong heterogeneity of the bargaining power across industries in the manufacturing sector. We have in fact conducted our estimates for different industries, at a level of aggregation which corresponds to the industry collective bargaining level, and it still appeared that the bargaining power fluctuates around 0.2.

The second main result of the paper is to give an empirical support to the theory of equalizing wage differences. When workers bargain over wages in a dynamic framework, they face a trade-off between the average level of wages and the risk (at the firm level) of being unemployed. Even in a regulated labor market, we find a competitive mechanism of compensations. This result is robust across industries. We hence do not find a strong bargaining power, but we show that wages may be influenced by some insurance mechanisms: in firms where few jobs are removed, workers get a lower wage. Although they are exogenous, these differences in job destruction rates can hence be interpreted as risk premia which reflect the price to be insured against unemployment risk. This result may explain inter-firm wage differences, which are really firm specific effects and do not reflect unobserved heterogeneity of workers.

We would like to thank Laurence Allain, Bruno Crépon, Francis Kramarz, Guy Laroque, Patrick Sevestre, and Henri Snessens for helpful comments on previous drafts of the 
paper and also the participants of the European Association of Labour Economists meeting (September 1997) and the participants of the Journeys of Applied Microeconomics (Summer 1998). In preparing the data we have greatly benefited from the work of Marianne Pauchet. We also thank one referee for his very helpful comments and advises. 


\section{References}

Abowd J. and Allain L. (1996), «Compensation Structure and Product Market Competition », Annales d'Economie et de Statistique, N 41/42 pp.207-217.

Abowd J., Corbel P. and Kramarz F.(1997), «The Entry and Exit of Workers and the Growth of Employment: an Analysis of French Establishments », The review of Economics and Statistics, Vol. $81 \mathrm{~N}^{\circ} 2$, pp.170-187.

Abowd J., Kramarz F. and Margolis D.(1999), « High Wages Workers and High Firms », Econométrica, Vol 67 N², pp.251-334.

Abowd J. and Lemieux T. (1993), «The effects of Product Market Competition», Quarterly Journal of Economics, $\mathrm{N}^{\circ} 435$ pp.983-1010.

Aghion P., Howitt P., (1992), “A model of growth through creative destruction", Econometrica, Vol 60, №2, pp.323-351.

Araï M., Ballot G. and Skalli A. (1996), «Différentiels intersectoriels de salaire et caractéristiques des employeurs en France », Economie et Statistique, no.299 pp.37-56.

Arellano M. and Bond S. (1991) «Some tests of specification for panel data : Monte-Carlo evidence and an application to employment equations », Review of Economic Studies, 58, pp.277-297.

Bénassy J-P. (1987), «Imperfect Competition Unemployment and Policy », European Economic Review, vol. 31 pp.417-426.

Beaudry P. and Di Nardo J. (1991), « The Effect of Implicit Contracts on the Movement of Wages over the Business Cycle: Evidence from Microdata», Journal of Political Economy, XCIX, pp.665-688.

Blanchflower D.G. Oswald A.J. and Sanfey P. (1996), «Wages, Profits and RentSharing » Quarterly Journal of Economics, N444 pp.227-252.

Brown J. and Ashenfelter O. (1986), « Testing the Efficiency of Employment Contracts », Journal of Political Economy, 94, S40-S87. 
Burda M. and Wysplosz C. (1994), «Gross Workers and Job Flows in Europe», European Economic Review, 38, pp.1287-1315.

Card D. (1996), «The Effect of Unions on the Structure of Wages: A Longitudinal Analysis », Econometrica, Vol.64, no.4, July.

Cahuc P. and Zylberberg A. (1996), «Economie du Travail », De Boeck Université.

Cahuc P. and Zylberberg A. (1996), «Le modèle WS-PS», Annales d'Economie et de Statistique, $\mathrm{N}^{\circ} 53$, pp.1-30.

Christofides L.N. and Oswald A.J. (1992), «Real Wage Determination and Rent-Sharing in Collective Bargaining Agreements », Quarterly Journal of Economics, Vol. 107, pp.985-1002.

Dormont B. (1994), «Quelle est l'influence du coût du travail sur l'emploi », Revue Economique, Vol. 45 N³, pp.399-414.

Goux D. and Maurin E. (1999), «Persistence of Inter Industry Wage Differentials : A Reexamination using Matched Worker-Firm Panel Data », Journal of Labor Economics, Vol. $17 \mathrm{~N}^{\circ} 3$, pp.492-533.

Hamermesch D (1993), « Labor Demand », Princeton University Press.

Lagarde S., Maurin E. and Torelli C. (1995), «Flux d'emplois et flux de main d'oeuvre en France : une étude sur la période 1987-1992 », Revue Economique, 47(3), mai.

Layard R., Nickell S.J. and Jackman R. (1991), «Unemployment», Oxford, Oxford University Press.

Manning A. (1993), «Wage bargaining and The Philips Curve: the identification and specification of aggregate wage equations », Economic Journal, vol.103, pp.98-118.

Murphy K.M. and Topel R.H. (1987), «Unemployment, Risk, and Earnings : Testing for Equalizing Wage Differences in the Labor Market», in Unemployment and the Structure of Labor Markets, edited by Kevin Lang and Jonathan S. Leonard. London: Basil Blackwell. 
Nickell S.J. and Andrews M. (1983), «Unions, Real Wages, and Employment in Britain 1951-1979 », Oxford Economic Papers, vol.35. pp.183-206.

Nickell S. and Wadhwani S. (1991), «Insider Forces and Wage Determination», Economic Journal, vol.100 pp.496-509.

OECD (1994), «Etude de l'OCDE sur l'emploi », volume 2, Paris.

OECD (1996), «Employment outlooks », Paris.

Rose N.L. (1987), «Labor Rent Sharing and Regulation: Evidence from the Trucking Industry », Journal of Political Economy, 95(6), pp.1146-1178.

Sargan J.D. (1958), «The Estimation of Economic Relationships Using Instrumental Variables », Econometrica, Vol. 26 N³, pp.393-415.

Van Reenen J. (1996), « The Creation and Capture of Rents: Wages and Innovation in a panel of UK companies », Quarterly Journal of Economics, N444 pp.195-226. 
Appendix 1 : The sequence of decisions in each firm

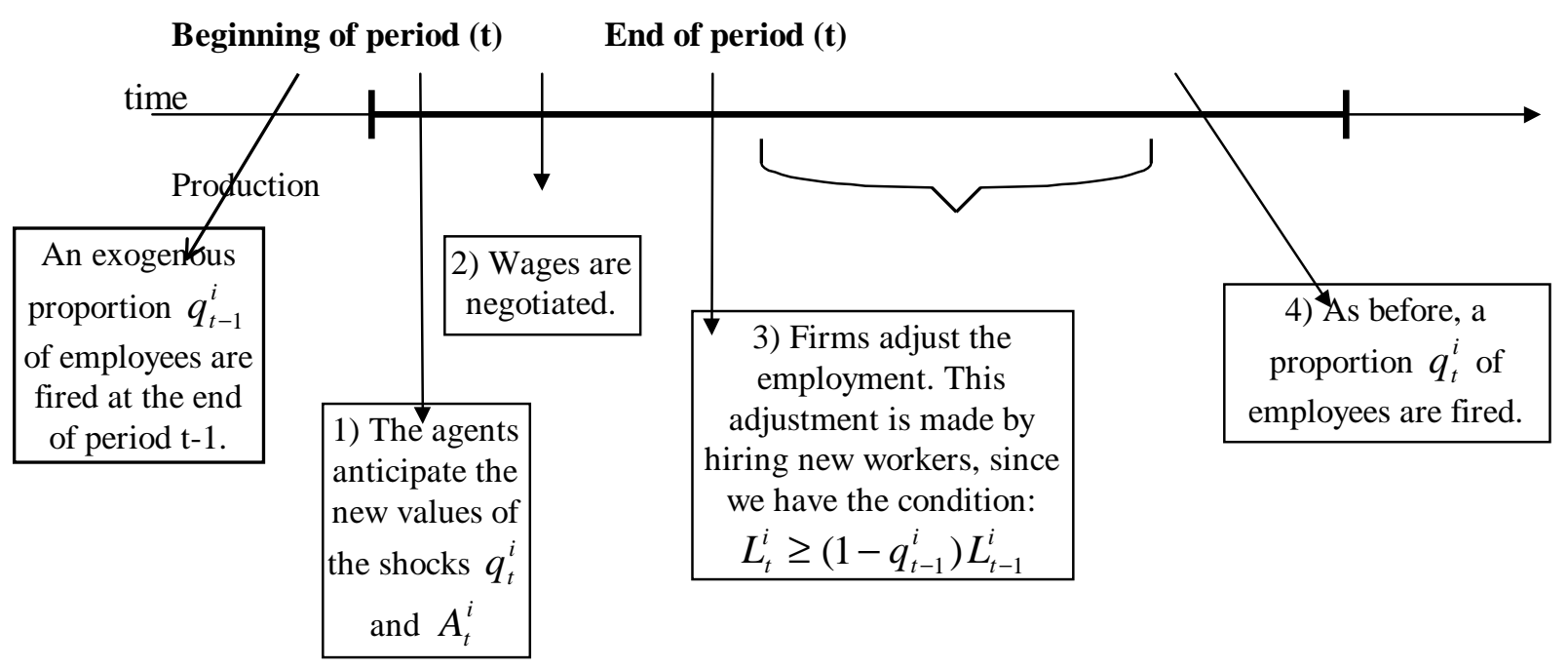




\section{Appendix 2: Wage equation in the case of an efficient contract}

When unions bargain over wages and employment (it means that the level of employment is one of the insider's objective even if they know they will keep their job until the end of the period), the new program is given by :

$$
\underset{w_{t}^{i}, L_{t}^{i}}{\operatorname{ar}}\left[R\left(\mathrm{~A}_{\mathrm{t}}^{\mathrm{i}} L_{t}^{i}\right)-\rho_{\mathrm{t}} w_{t}^{i} L_{t}^{i}\right]^{1-\gamma}\left[L_{t}^{i}\left(V_{t}^{i}-V_{t}^{g}\right)\right]^{\gamma}
$$

and the first order conditions are :

$$
\begin{aligned}
& V_{t}^{i}-V_{t}^{g}=\frac{\gamma}{1-\gamma}\left[\frac{R\left(A_{t}^{i} L_{t}^{i}\right)}{\rho_{t} L_{t}^{i}}-w_{t}^{i}\right] \\
& \mathrm{A}_{\mathrm{t}}^{\mathrm{i}} \frac{\partial R}{\partial L}\left(A_{t}^{i} L_{t}^{i}\right)=\rho_{t} w_{t}^{i}-\frac{\gamma}{1-\gamma}\left[\frac{R\left(A_{t}^{i} L_{t}^{i}\right)}{L_{t}^{i}}-\rho_{t} w_{t}^{i}\right]
\end{aligned}
$$

In the « efficient contract» model, the level of employment is higher than in the « right to manage » model and wages are lower (since the productivity is decreasing in $\mathrm{L}$ if $\mathrm{R}$ is concave). It is worth remarking that equation (A1) is formally identical to equation (8) in the paper. The only difference is that firms are no more on their labour demand curve (workers are paid above their marginal productivity). 
Appendix 3 : Empirical results

Table 1 : Summary Statistics

\begin{tabular}{lccc}
\hline \hline & Mean & $\begin{array}{c}\text { Minimum } \\
\text { Value }\end{array}$ & $\begin{array}{c}\text { Maximum } \\
\text { Value }\end{array}$ \\
\hline $\begin{array}{l}\text { Real gross wage (weighted by the structure of } \\
\text { employment) in constant 1980 Francs. }\end{array}$ & $\begin{array}{c}65438 \\
(11654)\end{array}$ & 29371 & 147433 \\
$\begin{array}{l}\text { Productivity per worker (also weighted by the } \\
\text { structure of employment) in 1980 Francs. }\end{array}$ & $\begin{array}{l}98198 \\
(35407)\end{array}$ & 31442 & 442105 \\
Rate of Job Destruction & 0.108 & 0 & 1 \\
\hline \hline
\end{tabular}

Source : Panel BIC-DMMO-ESE, 1988-1992, Insee.

Note : Standard Deviation in parentheses.

Table 2 : Decomposition of total variance

\begin{tabular}{lccc}
\hline \hline & \% Between & \% Within & Total Variance \\
\hline Real gross wage per Worker & 97.29 & 2.71 & 100 \\
Productivity per Worker & 97.83 & 2.17 & 100 \\
Rate of Job Destruction & 93.19 & 6.81 & 100 \\
\hline \hline
\end{tabular}

Source : Panel BIC-DMMO-ESE, 1988-1992, Insee. 
Table 3 : Annual average rates of Entry/Exit of workers in the BIC-ESE-DMMO panel.

\begin{tabular}{|l|l|c|c|c|c|c|}
\hline & & $\mathbf{1 9 8 8}$ & $\mathbf{1 9 8 9}$ & $\mathbf{1 9 9 0}$ & $\mathbf{1 9 9 1}$ & $\mathbf{1 9 9 2}$ \\
\hline \multirow{4}{*}{$\begin{array}{l}\text { All firms of the } \\
\text { sample }\end{array}$} & Entry rate & 0.19 & 0.22 & 0.20 & 0.15 & 0.13 \\
\cline { 2 - 7 } & Total exit rate & 0.18 & 0.20 & 0.19 & 0.17 & 0.15 \\
\cline { 2 - 7 } & Quit rate & 0.04 & 0.05 & 0.05 & 0.04 & 0.03 \\
\cline { 2 - 7 } & Rate of Job Destruction & 0.11 & 0.12 & 0.11 & 0.10 & 0.10 \\
\hline \multirow{4}{*}{$\begin{array}{l}\text { Firms with increasing } \\
\text { employment }\end{array}$} & Entry rate & - & 0.24 & 0.22 & 0.17 & 0.15 \\
\cline { 2 - 7 } & Total exit rate & - & 0.21 & 0.20 & 0.18 & 0.16 \\
\cline { 2 - 7 } & Quit rate & - & 0.06 & 0.06 & 0.043 & 0.029 \\
\cline { 2 - 7 } & Rate of Job Destruction & - & 0.12 & 0.12 & 0.11 & 0.11 \\
\hline \multirow{4}{*}{$\begin{array}{l}\text { Firms with decreasing } \\
\text { employment }\end{array}$} & Entry rate & - & 0.19 & 0.17 & 0.13 & 0.11 \\
\cline { 2 - 7 } & Total exit rate & - & 0.18 & 0.18 & 0.16 & 0.15 \\
\cline { 2 - 7 } & Quit rate & - & 0.05 & 0.05 & 0.04 & 0.03 \\
\cline { 2 - 7 } & Rate of Job Destruction & - & 0.11 & 0.11 & 0.10 & 0.10 \\
\hline
\end{tabular}

Source : BIC-ESE-DMMO panel 1988-1992, Insee (sample size : 915 firms).

Reading : The entry rate includes long term hiring contracts (CDI) and short-term hiring contract (CDD). The total exit rate includes lay-offs, endings of short term contracts, quits and other exits (retirements, military service, deaths...). The rate of job destruction $\left(q_{t}^{i}\right)$ we consider in the paper includes lay-offs and endings of short term contracts and excludes voluntary quits. 
Table 4 : OLS, Between, Within and FGLS estimates

\begin{tabular}{ccccc}
\hline \hline $\begin{array}{c}\text { Dependent } \\
\text { Variable } \mathrm{w}\end{array}$ & OLS & Within & Between & FGLS \\
\hline $\begin{array}{c}\text { Bargaining power } \\
(\gamma)\end{array}$ & 0.22 & 0.18 & 0.23 & 0.19 \\
$\begin{array}{c}\text { Bargaining power } \\
\text { time discount factor } \\
(\gamma \beta)\end{array}$ & $0.01)$ & $(0.02)$ & $(0.01)$ & $(0.01)$ \\
\hline $\mathrm{R}^{2}$ & $0.05)$ & $(0.04)$ & 0.12 & 0.16 \\
\hline \hline
\end{tabular}

Source : Panel BIC-DMMO-ESE, 1988-1992, Insee.

Note : Standard errors are indicated in parentheses.

Estimations are robust to heteroscedasticity and autocorrelation and include industrial cross time dummies.

Tests of the existence of an individual effect :

Fischer test : $\frac{\sigma_{B}^{2}}{\sigma_{W}^{2}}=3.952>F_{5 \%}(3648,3656)$

Tests of the exogeneity of the individual effect :

Hausman test : $8.73>\chi_{95 \%}(2)$

Table 5 : Within, first differences and long differences.

\begin{tabular}{cccc}
\hline \hline \multirow{2}{*}{$\begin{array}{c}\text { Mependent } \\
\text { Variable w }\end{array}$} & Within firm & First differences & Long differences \\
\cline { 2 - 4 } & 0.18 & 0.16 & 0.16 \\
Bargaining power & $(0.02)$ & $(0.01)$ & $(0.01)$ \\
$(\gamma)$ & 0.15 & 0.27 & 0.16 \\
Bargaining power time & $(0.04)$ & $(0.03)$ & $0.01)$ \\
discount factor & & & 0.35 \\
$(\gamma \beta)$ & 0.28 & 0.23 & \\
\hline $\mathrm{R}^{2}$ & &
\end{tabular}

Source : Panel BIC-DMMO-ESE, 1988-1992, Insee.

Note : Standard errors are indicated in parentheses.

Estimations are robust to heteroscedasticity and autocorrelation and include industrial cross time dummies. 
Table 6 : Within and FGLS estimations by industry

\begin{tabular}{|c|c|c|c|c|c|c|c|c|}
\hline \multirow[b]{2}{*}{ Industry } & \multicolumn{3}{|c|}{ Within } & \multicolumn{3}{|c|}{ FGLS } & \multicolumn{2}{|c|}{ Tests } \\
\hline & $\gamma$ & $\gamma \beta$ & $\mathrm{R}^{2}$ & $\gamma$ & $\gamma \beta$ & $\mathrm{R}^{2}$ & $\mathrm{~F}$ & $\begin{array}{c}\text { Haus- } \\
\text { man }\end{array}$ \\
\hline $\begin{array}{l}\text { I. Intermediate } \\
\text { Manufactured Products } \\
(N=383)\end{array}$ & $\begin{array}{c}0.13 \\
(0.01)\end{array}$ & $\begin{array}{l}0.13 \\
(0.04)\end{array}$ & 0.22 & $\begin{array}{c}0.15 \\
(0.01)\end{array}$ & $\begin{array}{c}0.11 \\
(0.04)\end{array}$ & 0.31 & 3.59 & 12.76 \\
\hline $\begin{array}{l}\text { I.1) Mining, Metal, Steel } \\
\text { basic industries and } \\
\text { Materials }(\mathrm{N}=72)\end{array}$ & $\begin{array}{c}0.09 \\
(0.01)\end{array}$ & $\begin{array}{c}0.07 \\
(0.07)\end{array}$ & 0.17 & $\begin{array}{c}0.12 \\
(0.02)\end{array}$ & $\begin{array}{c}0.08 \\
(0.08)\end{array}$ & 0.22 & 4.541 & 9.63 \\
\hline I.2) Chemicals $(\mathrm{N}=49)$ & $\begin{array}{c}0.06 \\
(0.01)\end{array}$ & $\begin{array}{c}0.04 \\
(0.11)\end{array}$ & 0.18 & $\begin{array}{c}0.08 \\
(0.01)\end{array}$ & $\begin{array}{c}0.01 \\
(0.09)\end{array}$ & 0.23 & 5.97 & 8.69 \\
\hline $\begin{array}{l}\text { I.3) Metal-Founding, } \\
\text { Metalwork }(\mathrm{N}=155)\end{array}$ & $\begin{array}{c}0.25 \\
(0.03)\end{array}$ & $\begin{array}{c}0.11 \\
(0.05)\end{array}$ & 0.35 & $\begin{array}{c}0.26 \\
(0.03)\end{array}$ & $\begin{array}{c}0.06 \\
(0.05)\end{array}$ & 0.41 & 2.19 & 8.26 \\
\hline $\begin{array}{l}\text { I.4) Paper and board } \\
\text { industry } \\
(\mathrm{N}=42)\end{array}$ & $\begin{array}{c}0.10 \\
(0.02)\end{array}$ & $\begin{array}{c}0.32 \\
(0.12)\end{array}$ & 0.23 & $\begin{array}{c}0.12 \\
(0.02)\end{array}$ & $\begin{array}{c}0.33 \\
(0.15)\end{array}$ & 0.28 & 5.21 & 2.10 \\
\hline $\begin{array}{l}\text { I.5) Rubber Products } \\
(\mathrm{N}=65)\end{array}$ & $\begin{array}{c}0.23 \\
(0.04)\end{array}$ & $\begin{array}{c}0.28 \\
(0.11)\end{array}$ & 0.45 & $\begin{array}{c}0.22 \\
(0.03)\end{array}$ & $\begin{array}{c}0.28 \\
(0.08)\end{array}$ & 0.50 & 2.87 & 0.167 \\
\hline $\begin{array}{l}\text { II. Equipment Goods } \\
(N=253)\end{array}$ & $\begin{array}{c}0.23 \\
(0.01)\end{array}$ & $\begin{array}{c}0.21 \\
(0.05)\end{array}$ & 0.35 & $\begin{array}{c}0.22 \\
(0.03)\end{array}$ & $\begin{array}{c}0.22 \\
(0.06)\end{array}$ & 0.35 & 2.52 & 1.69 \\
\hline $\begin{array}{l}\text { II.1) Houseware and } \\
\text { Electrical Machinery } \\
(\mathrm{N}=58)\end{array}$ & $\begin{array}{c}0.15 \\
(0.03)\end{array}$ & $\begin{array}{c}0.16 \\
(0.09)\end{array}$ & 0.28 & $\begin{array}{c}0.17 \\
(0.02)\end{array}$ & $\begin{array}{c}0.12 \\
(0.10)\end{array}$ & 0.35 & 3.06 & 3.64 \\
\hline $\begin{array}{l}\text { II.2) Machinery, Rail and } \\
\text { Road transportation } \\
\text { Equipment }(\mathrm{N}=195)\end{array}$ & $\begin{array}{c}0.26 \\
(0.01)\end{array}$ & $\begin{array}{c}0.19 \\
(0.06)\end{array}$ & 0.37 & $\begin{array}{c}0.24 \\
(0.01)\end{array}$ & $\begin{array}{c}0.25 \\
(0.08)\end{array}$ & 0.38 & 2.24 & 0.44 \\
\hline $\begin{array}{l}\text { III. Consumer Goods } \\
(N=279)\end{array}$ & $\begin{array}{c}0.21 \\
(0.01)\end{array}$ & $\begin{array}{c}0.10 \\
(0.05)\end{array}$ & 0.33 & $\begin{array}{c}0.23 \\
(0.01)\end{array}$ & $\begin{array}{c}0.14 \\
(0.01)\end{array}$ & 0.40 & 5.38 & 9.16 \\
\hline $\begin{array}{l}\text { III.1) Textile, Leather and } \\
\text { Footwear }(\mathrm{N}=138)\end{array}$ & $\begin{array}{c}0.21 \\
(0.03)\end{array}$ & $\begin{array}{c}0.11 \\
(0.05)\end{array}$ & 0.31 & $\begin{array}{c}0.23 \\
(0.01)\end{array}$ & $\begin{array}{c}0.11 \\
(0.06)\end{array}$ & 0.39 & 5.52 & 1.21 \\
\hline $\begin{array}{l}\text { III.2) Wood and Furnitures } \\
(\mathrm{N}=90)\end{array}$ & $\begin{array}{c}0.23 \\
(0.03)\end{array}$ & $\begin{array}{c}0.37 \\
(0.10)\end{array}$ & 0.36 & $\begin{array}{c}0.23 \\
(0.02)\end{array}$ & $\begin{array}{c}0.28 \\
(0.09)\end{array}$ & 0.37 & 2.91 & 4.39 \\
\hline $\begin{array}{l}\text { III.3) Printing and } \\
\text { Publishing } \\
(\mathrm{N}=51)\end{array}$ & $\begin{array}{c}0.21 \\
(0.05)\end{array}$ & $\begin{array}{l}-0.03 \\
(0.08)\end{array}$ & 0.34 & $\begin{array}{c}0.20 \\
(0.05)\end{array}$ & $\begin{array}{c}0.01 \\
(0.06)\end{array}$ & 0.34 & 6.98 & 0.15 \\
\hline
\end{tabular}

Source : Panel BIC-DMMO-ESE, 1988-1992, Insee.

Note $: N=$ number of firms in the industry.

Standard errors in parentheses.

Estimations include industrial cross time dummies. 
Table 7 : GMM estimates

\begin{tabular}{|c|cc||cc||cc|}
\hline \hline \multirow{2}{*}{$\begin{array}{c}\text { Dependent } \\
\text { variable w }\end{array}$} & \multicolumn{2}{|c||}{ Model (a) } & \multicolumn{2}{c||}{ Model (b) } & \multicolumn{2}{c|}{ Model ( } \\
\cline { 2 - 7 } & $\begin{array}{c}\text { GMM1 } \\
\text { (first step) }\end{array}$ & $\begin{array}{c}\text { GMM2 } \\
\text { (two step) }\end{array}$ & $\begin{array}{c}\text { GMM1 } \\
\text { (first step) }\end{array}$ & $\begin{array}{c}\text { GMM2 } \\
\text { (two step) }\end{array}$ & $\begin{array}{c}\text { GMM1 } \\
\text { (first step) }\end{array}$ & $\begin{array}{c}\text { GMM2 } \\
\text { (two step) }\end{array}$ \\
\hline$\gamma$ & 0.20 & 0.21 & 0.08 & 0.08 & 0.19 & 0.19 \\
& $(0.04)$ & $(0.03)$ & $(0.05)$ & $(0.04)$ & $(0.05)$ & $(0.04)$ \\
$\gamma \beta$ & 0.07 & 0.08 & 0.12 & 0.12 & 0.13 & 0.14 \\
& $(0.05)$ & $(0.05)$ & $(0.04)$ & $(0.04)$ & $(0.04)$ & $(0.04)$ \\
$\beta$ & 0.35 & 0.38 & 1.49 & 1,50 & 0.68 & 0.77 \\
& $(0.15)$ & $(0.14)$ & $(0.54)$ & $(0.54)$ & $(0.08)$ & $(0.07)$ \\
\hline \multirow{2}{*}{$\begin{array}{c}\text { Sargan test } \\
\text { (p-value) }\end{array}$} & \multicolumn{2}{|c|}{34.0} & \multicolumn{2}{c|}{29.8} & \multicolumn{2}{c|}{50.5} \\
\hline \hline
\end{tabular}

Source : Panel BIC-DMMO-ESE, 1988-1992, Insee.

Note: standard errors are reported in parentheses.

Estimations include industrial cross time dummies.

The instrumental variables are :

Model (a) Exogenous instruments :

import and export prices, regional unemployment rate, Herfindhal index (at t, t-1, t-2).

Model (b) Lagged instruments :

quasi-rent per worker, regional wage and turnover rate (at t-2, t-3, t-4).

Model (c) Exogenous instruments + Lagged instruments (a)+(b).

The standard error of $\hat{\beta}$ is computed from the matrice of variance of $(\hat{\gamma \beta}, \bar{\gamma})$.

Test of compatibility of both sets of instruments :

$\operatorname{Sargan}(\mathrm{x})-\operatorname{Sargan}(\mathrm{y})<\chi_{95 \%}(D F(x)-D F(y))$ for $\mathrm{x}=\mathrm{c}$ and $\mathrm{y}=\mathrm{a}$ and $\mathrm{b}$, where DF is the number of degrees of freedom. 
Table 8: GMM estimates by industry

\begin{tabular}{lccccc}
\hline \hline & \multicolumn{2}{c}{ GMM1 } & GMM2 & Sargan \\
\hline Industry & $\gamma$ & $\gamma \beta$ & $\gamma$ & $\gamma \beta$ & $\begin{array}{c}\text { (p- } \\
\text { value })\end{array}$ \\
\hline I. Intermediate Manufactured Products & 0.12 & 0.11 & 0.12 & 0.13 & 0.38 \\
(N=383) & $(0.04)$ & $(0.05)$ & $(0.02)$ & $(0.04)$ & \\
I.1) Mining, Metal, Steel basic industries & 0.08 & 0.23 & 0.08 & 0.12 & 0.71 \\
and Materials (N=72) & $(0.03)$ & $(0.13)$ & $(0.01)$ & $(0.06)$ & \\
I.2) Chemicals (N=49) & - & - & - & - & - \\
I.3) Metal-Founding, Metalwork (N=155) & 0.33 & 0.11 & 0.33 & 0.08 & 0.11 \\
& $(0.06)$ & $(0.07)$ & $(0.03)$ & $(0.04)$ & \\
I.4) Paper and board industry & - & - & - & - & - \\
(N=42) & & & & & \\
I.5) Rubber Products (N=65) & 0.21 & 0.21 & 0.23 & 0.18 & 0.18 \\
& $(0.07)$ & $(0.14)$ & $(0.03)$ & $(0.07)$ & \\
& & & & & \\
II. Equipment Goods (N=253) & 0.23 & 0.14 & 0.19 & 0.13 & 0.79 \\
& $(0.05)$ & $(0.09)$ & $(0.02)$ & $(0.05)$ & \\
II.1) Houseware and Electrical & 0.26 & 0.16 & 0.23 & 0.17 & 0.72 \\
Machinery (N=58) & $(0.06)$ & $(0.12)$ & $(0.01)$ & $(0.05)$ & \\
II.2) Machinery , Rail and Road & 0.19 & 0.14 & 0.16 & 0.20 & 0.70 \\
transportation Equipment (N=195) & $(0.04)$ & $(0.11)$ & $(0.03)$ & $(0.06)$ & \\
& & & & & \\
III. Consumer Goods & & & & & \\
(N=279) & 0.24 & 0.10 & 0.17 & 0.16 & 0.46 \\
III.1) Textile, Leather and Footwear & $(0.05)$ & $(0.06)$ & $(0.04)$ & $(0.05)$ & \\
(N=138) & 0.24 & 0.07 & 0.23 & 0.10 & 0.55 \\
III.2) Wood and Furnitures & $(0.06)$ & $(0.07)$ & $(0.03)$ & $(0.04)$ & \\
(N=90) & 0.24 & 0.25 & 0.23 & 0.22 & 0.14 \\
III.3) Printing and Publishing & $(0.06)$ & $(0.15)$ & $(0.02)$ & $(0.064)$ & \\
(N=51) & 0.26 & 0.23 & 0.26 & 0.16 & 0.29 \\
\hline \hline & $(0.18)$ & $(0.24)$ & $(0.15)$ & $(0.17)$ & \\
\hline
\end{tabular}

Source : Panel BIC-DMMO-ESE, 1988-1992, Insee.

Note : Standard errors in parentheses.

The set of instruments used is the same as the one described in table 9.

Estimations include industrial cross time dummies. 


\section{IZA Discussion Papers}

No.

Author(s)

567

H. Lehmann

K. Phillips

J. Wadsworth

568

H. O. Duleep

D. J. Dowhan

569

J. Haltiwanger

M. Vodopivec

570

T. K. Bauer

S. Bender

571

O. Ashenfelter

M. Greenstone

572

C. Y. Co

I. N. Gang

M.-S. Yun

573

R. T. Riphahn

O. Serfling

574

R. Kuhn

S. Stillman

575

H. Antecol

D. A. Cobb-Clark

S. J. Trejo

576

M. Fertig

C. M. Schmidt

H. Schneider

577

K. Ariga

G. Brunello
I. N. Gang
F. L. Rivera-Batiz
M.-S. Yun

579

I. N. Gang

M.-S. Yun

580

I. N. Gang

J. Landon-Lane

M.-S. Yun

581

P. Cahuc

F. Malherbet

582
P. Cahuc

C. Gianella

D. Goux

A. Zylberberg
Title

Area

Date

The Incidence and Cost of Job Loss in a

Transition Economy: Displaced Workers in

Estonia, 1989-1999

Revisiting the Family Investment Model with

Longitudinal Data: The Earnings Growth of Immigrant and U.S.-Born Women

Worker Flows, Job Flows and Firm Wage

Policies: An Analysis of Slovenia

Technological Change, Organizational

Change, and Job Turnover

1

Using Mandated Speed Limits to Measure the

5

Value of a Statistical Life

Self-Employment and Wage Earning:

4

Hungary During Transition

Item Non-Response on Income and Wealth

6

09/02

Questions

Understanding Interhousehold Transfers in a

4

Transition Economy: Evidence from Russia

Human Capital and Earnings of Female

Immigrants to Australia, Canada, and the

United States

Active Labor Market Policy in Germany -

Is There a Successful Policy Strategy?

6

09/02

Are the More Educated Receiving More

Training? Evidence from Thailand

Economic Strain, Ethnic Concentration and

09/02

Attitudes Towards Foreigners in the European

1

Union

Decomposing Inequality Change in East

Germany During Transition

4

09/02

Gender Differences in German Upward Income 1

09/02

Mobility

Unemployment Compensation Finance and

5

09/02

Labor Market Rigidity

Equalizing Wage Differences and Bargaining

6

09/02 